\title{
Fluorimetric assay of mycobacterial group-specific hydrolase enzymes
}

\author{
J. M. GRANGE \\ From the Cardiothoracic Institute, Brompton Hospital, Fulham Road, London SW3 6HP, UK
}

SUMMARY Fluorigenic substrates prepared from 4-methylumbelliferone provide a simple, convenient method for detecting and assaying group-specific hydrolase activity in small quantities of whole mycobacteria. Physico-chemical properties of the enzymes such as $\mathrm{pH}$ dependence and heat stability may also be studied. A technique is described for studying glycosidase, hexosaminidase, acid phosphatase, and acyl esterase activity in seven mycobacterial species. Such techniques will be a useful aid to the taxonomy, identification, and quantification of mycobacteria, especially slowly growing strains in which biochemical properties are very difficult to detect by other techniques.

Enzymic activities in many bacteria can be rapidly and accurately estimated. Unfortunately this is not the case in the genus Mycobacterium, in which even the so-called rapid growers have a relatively low metabolic rate. Enzymes may be studied in detail by extracting the required enzyme from a large mass of disrupted organisms (Diaz and Wayne, 1974), but tests requiring small quantitites of whole bacteria are preferable for routine identification and taxonomic studies. For this, very sensitive systems for detecting enzyme activity are needed.

A range of substrates linked to 4-methylumbelliferone (4-methyl-7-hydroxy-coumarin) are commercially available for detecting and assaying group-specific hydrolase enzymes. After enzymic hydrolysis the free 4-methylumbelliferone fluoresces intensly in alkaline solution with a corresponding absorption of ultraviolet light at $362 \mathrm{~nm}$ (Leaback, 1975).

Grange and Clark (1977) found 4-methylumbelliferone-linked substrates suitable for spectrophotometric estimations of mycobacterial glucosidase and arylsulphatase. I investigated the possibility of using 4-methylumbelliferone-linked substrates to study the presence, quantity, and properties of a range of mycobacterial acid groupspecific hydrolases, including glycosidases, hexosaminidases, acid phosphatases and acyl esterases.

\section{Material and methods}

Mycobacterium chelonei ATCC 19237, M. duvalii NCTC 514, M. fortuitum ATCC 6841, M. smegmatis

Received for publication 28 September 1977
ATCC $607, M$. kansasii (clinical isolate), $M$. marinum (clinical isolate), and M. tuberculosis var. bovis BCG (Pasteur) were maintained on Löwenstein Jensen medium.

The following 4-methylumbelliferyl (4-MU)-linked substrates were purchased from Koch Light Laboratories Ltd: 4-MU- $\beta$-D-glucopyranoside, 4-MU- $\beta$-Dgalactopyranoside, 4-MU- $\alpha$-L-arabinopyranoside, 4-MU- $\alpha$-D-mannopyranoside, 4-MU- $\beta$-D-glucuronide, 4-MU-phosphate, 4-MU-2-acetamido-2deoxy- $\beta$-D-glucopyranoside, and 4-MU-2-acetamido-2-deoxy- $\beta$-D-galactopyranoside. The last two substrates were for estimating $\mathrm{N}$-acetyl glucosaminidase and $\mathrm{N}$-acetyl galactosaminidase respectively. The acyl esters of fatty acids were 4-MU acetate, 4-MU propionate, 4-MU butyrate, 4-MU heptanoate, 4-MU nonanoate, 4-MU oleate, 4-MU elaidate, and 4-MU palmitate.

The bacteria were harvested from Löwenstein Jensen medium and suspended in distilled water at a concentration of $20 \mathrm{mg}$ wet weight $/ \mathrm{ml}$. Clumps of bacteria were dispersed by agitation on a vortex mixer. In preliminary studies the bacteria were washed, but this was found to be unnecessary and was subsequently omitted.

The substrates were dissolved in dimethyl sulfoxide (grade 1, Sigma Biochemicals Ltd) to give 0.04-M stock solutions except for the oleate, elaidate, and palmitate esters, which, owing to solubility, were prepared as $0.02-\mathrm{M}$ solutions. The stock solutions were stored at $-20^{\circ} \mathrm{C}$. Immediately before use $0.2 \mathrm{ml}$ phosphatase, glycosidase, and hexosaminidase substrates were added to $0.8 \mathrm{ml}$ of buffer at the required $\mathrm{pH} ; 0.2 \mathrm{ml}$ of acyl esterase substrates were added to $9 \cdot 8 \mathrm{ml}$ of buffer. 
All enzyme activities, with the exception of acid phosphatase, were estimated in phosphate buffer prepared by mixing $0 \cdot 2-\mathrm{M}$ solutions of $\mathrm{KH}_{2} \mathrm{PO}_{4}$ and $\mathrm{Na}_{2} \mathrm{HPO}_{4}$ to obtain $\mathrm{pH}$ values of $4 \cdot 5,5 \cdot 0$, $5 \cdot 5,6 \cdot 0,6 \cdot 5,7 \cdot 0,7 \cdot 5,8 \cdot 0$, and $8 \cdot 5$. Phosphatase activity was estimated in citrate buffer prepared by mixing $\mathbf{0 . 2} \mathrm{M}$ solutions of citric acid and trisodium citrate to obtain $\mathrm{pH}$ values from $3 \cdot 5$ to $7 \cdot 0$.

Sodium glycinate buffer was prepared by adding $1.0 \mathrm{~N} \mathrm{NaOH}$ to a $0 \cdot 2-\mathrm{M}$ solution of glycine to give a pH of $10 \cdot 5$.

\section{ESTIMATION OF ENZYME ACTIVITY}

For estimating glycosidase, hexosaminidase, and phosphatase activity the reaction mixtures contained $0.1 \mathrm{ml}$ bacterial suspension, $0.1 \mathrm{ml}$ buffered substrate, and $0.8 \mathrm{ml}$ buffer. The reaction mixtures, contained in $15 \times 50 \mathrm{~mm}$ screwcap bottles, were incubated in a water bath at $37^{\circ} \mathrm{C}$. After incubation the reactions were stopped and the fluorescence developed by adding $1.0 \mathrm{ml}$ sodium glycinate buffer. The reaction mixture estimating acyl esterases contained $0.1 \mathrm{ml}$ bacterial suspension, $0.9 \mathrm{ml}$ buffer, and $1.0 \mathrm{ml}$ buffered substrate. Preliminary studies showed that the optimun $\mathrm{pH}$ for this group of enzymes was 8.0 to 8.5 but at this $\mathrm{pH}$ the blank value was unacceptably high owing to spontaneous hydrolysis of the substrate. Therefore all reactions were conducted at $\mathrm{pH} \mathbf{7 . 5}$ and the fluorescence was estimated without modifying the $\mathrm{pH}$.

Fluorescence was measured in $10-\mathrm{mm}$ quartz cuvettes in a Baird Atomic SF 100E spectrofluorimeter at an excitation wavelength of $362 \mathrm{~nm}$ and an emission wavelength of $450 \mathrm{~nm}$. The reaction mixtures were maintained at $37^{\circ} \mathrm{C}$ until the fluorescence was measured, as intensity of fluorescence is temperature-dependent.

The blank tubes contained $0 \cdot 1 \mathrm{ml}$ distilled water in place of bacteria and the constancy of the light source was checked by means of standard solutions of 4-methylumbelliferone in sodium glycinate buffer.

Phosphatase activity was estimated after three hours' incubation. Glycosidase and hexosaminidase activities were estimated after 18 hours' incubation. As the fluorescence produced by acyl esterase was measured without altering the $\mathrm{pH}$ of the reaction mixture these enzyme activities were estimated at intervals throughout the reaction.

\section{Results}

GLYCOSIDASE ACTIVITY

All strains had $\beta$-D-glucosidase activity with optimum $\mathrm{pH}$ of 6.5. $\alpha$-D-Mannosidase was detectable in $M$. chelonei, $M$. fortuitum, and $M$. smeg- matis. The activity of this enzyme was maximum at pH 7.0 with an additional smaller peak of activity at pH 6.0 (Fig. 1). A high level of $\beta$-D-galactosidase activity was detected in $M$. chelonei (about one-third the rate of $\beta$-D-glucosidase) with an optimum $\mathrm{pH}$ of 6.5. Only trace amounts of $\beta$-D-galactosidase activity were detectable in the other strains. No significant $\alpha$-L-arabinosidase activity was detectable in any strain.

$\beta$-D-glucuronidase activity was detectable in all strains. This enzyme was more $\mathrm{pH}$ dependent than the others (Fig. 1). All strains except $M$. chelonei showed a peak of $\beta$-D-glucuronidase activity at pH 5.5 but very little activity at pH 4.5. $M$. chelonei showed marked activity at $\mathrm{pH} 4 \cdot 5$. In an additional study using $0 \cdot 2-\mathrm{M}$ citrate buffer nine strains of $M$. chelone $i$ all showed an optimum $\mathrm{pH}$ of 4.5 or 5.0 for this enzyme.

\section{HEXOSAMINIDASE ACTIVITY}

The activities of $\mathrm{N}$-acetyl glucosaminidase and $\mathrm{N}$-acetyl galactosaminidase were very similar in distribution to the glucosidase and galactosidase activities respectively. The former enzmye was present in all strains with an optimum $\mathrm{pH}$ of 5.5 except for BCG, in which the optimum $\mathrm{pH}$ was $6 \cdot 0$. The latter enzyme was detected only in $M$. chelonei, with an optimum $\mathrm{pH}$ of $\mathbf{6 \cdot 5}$.

\section{ACID PHOSPHATASE ACTIVITY}

This enzyme varied considerably in activity and $\mathrm{pH}$ dependence from strain to strain. $M$. chelonei, M. fortuitum, M. marinum, M. kansasii, and BCG showed a relatively high level of activity. $M$. duvalii showed a low level of activity and $M$. smegmatis occupied an intermediate position (Fig. 2).

$M$. chelonei, M. smegmatis, and BCG showed a single peak of activity at $\mathrm{pH} 5.5$ and $M$. fortuitum

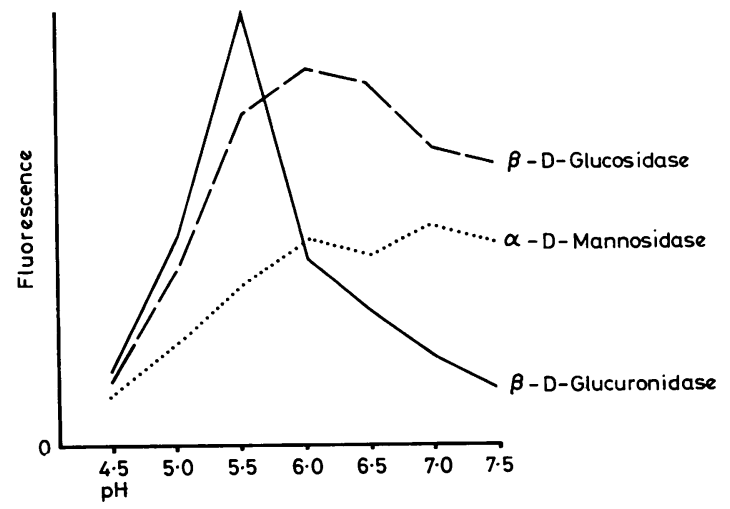

Fig. 1 Effect of $p H$ on $\beta$-D-glucosidase, $\alpha-D$-mannosidase, and $\beta-D$-glucuronidase activity of $\mathrm{M}$. fortuitum. 


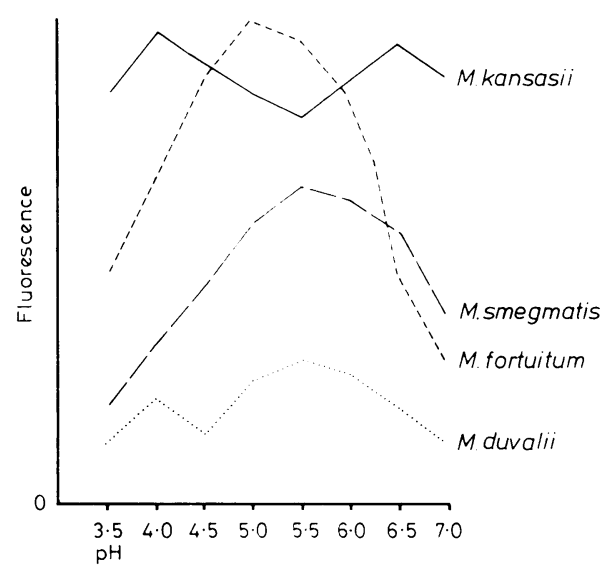

Fig. 2 Acid phosphatase activity of M. kansasii, M. smegmatis, M. fortuitum, and M. duvalii.

showed a similar peak at 5.0. M. marinum and $M$. kansasii gave two peaks of activity at $\mathrm{pH} 4$ and 6.5. M. duvalii gave peaks of activity at $\mathrm{pH} 4$ and $5 \cdot 5$.

Acid phosphatase varied in its heat stability. Preheating the bacteria at $70^{\circ} \mathrm{C}$ for 30 minutes caused less than $10 \%$ inactivation of enzyme (estimated at $\mathrm{pH} \mathrm{5.0)}$ in M. marinum, M. kansasii, and $M$. fortuitum but over $50 \%$ in the other four strains.

ACYL ESTERASE ACTIVITY

All the strains hydrolysed the eight acyl esters. In each case the esters of butyric and heptanoic acid were the most rapidly hydrolysed. The other esters were hydrolysed less rapidly in the order propionate $>$ acetate $>$ nonanoate $>$ palmitate $>$ oleate $>$ elaidate. Apart from variation in the absolute reaction rate the seven strains showed no significant difference in acyl esterase activity. As noted in the methods section, it was impracticable to estimate acyl esterase activity at the optimum $\mathrm{pH}$. The reactions were therefore conducted at a $\mathrm{pH}$ of $7 \cdot 5$. Phosphate buffered saline $\mathrm{pH} 7 \cdot 4$ (Dulbecco $\mathrm{A}$, Oxoid) was later found to be equally satisfactory.

Hydrolysis of the butyric acid ester depended on the concentration of bacteria present. Thus reaction mixtures containing a final concentration of $M$. fortuitum of $200,100,50$, and $25 \mu \mathrm{g} / \mathrm{ml}$ had reaction half times of $5,11,21$, and 43 minutes respectively. Acyl esterase activity correlated closely with turbidity of bacteria cultured in liquid Sauton medium. During the growth phase very little $(<2 \%)$ of the enzyme activity was detectable in culture filtrate but further incubation during the stationary phase caused an increasing amount of the enzyme to become extracellular.

BLANK VALUES

Excepting acyl esterase substrates at a high $\mathrm{pH}$, all substrates gave a very low constant fluorescence. High blank values were avoided by using freshly prepared buffered substrate and avoiding contamination of the solutions by bacteria and fungi. Such contamination caused high blank values which varied according to the $\mathrm{pH}$. The bacteria, cell-free extracts, and culture filtrates showed no detectable fluorescence at the excitation and emission wavelengths used. Routine use of enzyme blanks in addition to substrate blanks is therefore unnecessary.

\section{Discussion}

The aim of this study was to evaluate a technique for detecting, quantifying, and characterising groupspecific hydrolases in mycobacteria; not to investigate any particular taxonomic problem. The methods described should present no technical difficulties, but care must be taken throughout to avoid contamination with other bacteria since this can lead to falsely high blanks or results. A spectrofluorimeter was used, but the much less expensive fixed wavelength fluorimeters would be equally suitable. Free 4-metylumbelliferone may also be estimated by measuring ultraviolet absorption at $362 \mathrm{~nm}$ in a spectrophotometer (Grange and Clark, 1977). The fluorimeter, however, is more sensitive and the reaction mixtures need not be clarified by centrifugation before measuring the fluorescence. Although fluorescence is expressed in arbitrary units enzyme activity may be quantified by comparing the fluorescence of the test with that of standard solutions of umbelliferone.

Two of the enzymes referred to in this study have been detected by semi-quantitative colorimetric techniques in taxonomic studies of mycobacteria and related genera-namely, $\beta$-D-galactosidase (Tsukamura, 1974; Tacquet et al., 1966) and heatstable acid phosphatase (Saito et at., 1968). Sensitive fluorimetric techniques not only enable enzyme activity to be detected but also the physico-chemical properties such as heat stability and $\mathrm{pH}$ dependence to be accurately measured even in small quantities of slowly growing strains. Taxonomically it is much more logical to compare and contrast properties of enzymes which reflect their molecular structure than merely to screen strains for the presence of a given metabolic property. The former approach may also give clues to the evolutionary pathways within a genus, as is the case with immunodiffusion analysis of soluble mycobacterial antigens (Stanford, 1973). 
Detection of acyl esterase activity was in itself of no taxonomic value. On the other hand, assay of these enzymes, which appear to be constitutive, may be of value in determining bacterial viability and growth under a range of cultural conditions.

The use of fluorogenic substrates for studying enzyme function is becoming more popular among biochemists and an increasing number of substrates are becoming commercially available. It should therefore be possible to develop a unified and technically easy set of tests for use in taxonomic studies and, subsequently, routine identification of mycobacteria and related genera-especially the very slowly growing strains in which biochemical properties are very difficult to elicit by other techniques.

I thank Dr John Morley for lending me a spectrofluorimeter, Dr John Stanford for supplying the bacteria, and the Medical Art Department of the Royal Marsden Hospital for preparing the figures.

\section{References}

Diaz, G. A., and Wayne, L. G. (1974). Clarification of sonic lysates of Mycobacterium tuberculosis. American Review of Respiratory Disease, 109, 154-155.

Grange, J. M., and Clark, K. (1977). Use of umbelliferone derivatives in the study of enzyme activities of mycobacteria. Journal of Clinical Pathology, 30, 151-153.

Leaback, D. H. (1975). An Introduction to the Fluorimetric Estimation of Enzyme Activities, 2nd edition. Koch Light Laboratories Ltd., Colnbrook, England.

Tacquet, A., Tison, F., Polspoel, B., Roos, P., and Devulder, B. (1966). Etude de la beta-D-galactosidase des mycobactéries. Annales de l'Institut Pasteur, (Paris), 111, 86-89.

Tsukamura, M. (1974). Differentiation of the "Mycobacterium" rhodochrous group from nocardiae by beta-galactosidase activity. Journal of General Microbiology, 80, 553-555.

Saito, H., Hosokawa, H., and Tasaka, H. (1968). The heat stable acid phosphatase activity of mycobacteria. American Review of Respiratory Disease, 97, 474-476.

Stanford, J. L. (1973). Immunodiffusion analysis-a rational basis for the taxonomy of mycobacteria. Annales de la Société Belge de Médecine Tropicale, 53, 321-330. 